\title{
Critique of the category of despair in the poems of the Third Brotherhood with the approach of the Quran and the hadiths of the Imams (peace be upon them)
}

Crítica de la categoría de desesperación en los poemas de la Tercera Hermandad con el enfoque del Corán y los hadices de los imanes (la paz sea con ellos)

\author{
Azra Hatami \\ PhD student, Azad University, Mashhad Branch, Iran \\ Mohammad Badizadeh Beidakhti \\ Assistant Professor, Islamic Azad University, Mashhad Branch, Iran \\ Vida Ahmadi \\ Assistant Professor, Islamic Azad University, Mashhad Branch
}

*Correspondence

Email: AzraHatami@gmail.com
Cite as:

Hatami, A., Badizadeh, M., \& Ahmadi, V. (2021). Critique of the category of despair in the poems of the Third Brotherhood with the approach of the Quran and the hadiths of the Imams (peace be upon them). Propósitos y Representaciones, 9(SPE3), e1095. Doi: http://dx.doi.org/10.20511/pyr2021.v9nSPE3.1095 


\section{Summary}

What we are going to address in this article is the lexical introduction of the word despair, the meaning of the Word. Vocabulary, an introduction to the word from the perspective of etymology or the etymology of illusion. Such is the introduction of the various meanings of this word in terms of Quranic, literary and philosophical. The main purpose is to critique the concepts and works of despair in the poetry of the Third Brotherhood and the Western philosophers Spinoza and Nietzsche. This article emphasizes the critique of the poems of the Third Brotherhood for this purpose from the teachings of the Holy Quran. We have used the hadiths of the Ahl al-Bayt (peace be upon them) as a solution to critique and study this. Absurd thoughts with the school of nihilism. Undoubtedly, the issues raised in the Qur'an and Hadith can be the main criteria in this critique be us.

Keywords: Despair and Despair, Third Brotherhood, Divine Mercy, Quranic Messages, Western Spinoza and Nietzsche Philosophy.

\section{Resumen:}

Lo que vamos a abordar en este artículo es la introducción léxica de la palabra desesperación, el significado de la palabra. Vocabulario, una introducción a la palabra desde la perspectiva de la etimología o la etimología de la ilusión. Tal es la introducción de los diversos significados de esta palabra en términos coránicos, literarios y filosóficos. El propósito principal es criticar los conceptos y obras de la desesperación en la poesía de la Tercera Hermandad y los filósofos occidentales Spinoza y Nietzsche. Este artículo enfatiza la crítica de los poemas de la Tercera Hermandad con este propósito a partir de las enseñanzas del Sagrado Corán. Hemos utilizado los hadices de Ahl al-Bayt (la paz sea con ellos) como una solución para criticar y estudiar esto. Pensamientos absurdos con la escuela del nihilismo. Sin lugar a dudas, las cuestiones planteadas en el Corán y el Hadith pueden ser el criterio principal en esta crítica de nosotros.

Palabras clave: Desesperación y Desesperación, Tercera Hermandad, Divina Misericordia, Mensajes Coránicos, Spinoza Occidental y Filosofía de Nietzsche,

\section{Introduction}

The fasts pass one after the other. Months and years and this turn of time, sunrise and sunset. Roughness, joys and sorrows, a sense of youth and old age and vices and virtues. He becomes the guest of the heart of these travelers (humans). Sometimes such ecstasy and joy is used and

Shit on the back .... and with a little flood, this calm sea is turbulent. For a few mornings, love becomes the guest of our hearts and we do not know each other by beating our feet and having fun Once upon a time, a moody and violent secretary slapped all our possessions that no longer

It leaves no room for despair and distress. In these adventurous waves of human times, they are divided into two types:

Those who believe in the truth and once again in this fall the stones of their days to the verse

"Al-Bazkar Ahl al-Thammin al-Qulub" calms down and puts their hope and salvation in this

They see the great verse and find themselves "being" from the darkness of ignorance and ignorance to the white world. They convey and find the meaning of truth in themselves. A group is also immersed in this vortex of time and because the truth is clearly in their existence. They do not feel overwhelmed by "depravity" and "old age" and as they read the verse of despair.

The singers then come to their senses and are drowned in the darkness. The discussion in this article is critical to the same frustration and absurdity from a philosophical point of view paid. 
Disappointment and absurdity arise from a thought that destroys any value. Win and the absurdist; He sees every goal and achievement of every goal as meaningless and the consequences and. Harmful effects of this thinking have a social, personal, moral or political burden.

In this article, we intend to examine the critique of individual and social absurdism. And in contrast to a practical solution to get rid of emptiness and despair, which is necessary and inevitable

\section{Garlic Article}

1 -Definitive lexical of despair

2 - School of Nihilism

3. The Desperate Philosopher (Spinoza and Nietzsche)

4 - Victor Frankl treatment method

5-Brotherhood (Thoughts () Poems (

6- Therapeutic solution of Quran and Hadith

7 - Conclusion

8- List of sources and references

\section{Literary definition of despair}

First of all, to examine the meaning of the word despair and hopelessness in Dehkhoda dictionary and to examine it from. We pay attention to the eyes of the Holy Quran and the words of the infallibles. The meaning of the word despair in the dictionary of Dehkhoda is despair. Despair, misery and helplessness are the opposite hope. To be hopeless.

\section{Meaning of despair}

Article ("despair" is the opposite of greed and literally means the interruption and expectation of man to achieve something, Is itself.) 2) In moral terms, despair is a state that arises in the position of helplessness and inability in the human soul. Come and generally despair of something is called despair.) 3) Despair is a moral slip because it means oppressing oneself and suicide is gradual and absolute despair is death. Despair in the view of verses and narrations the following can be mentioned in Quranic and Islamic narrations about despair. "Only the disbelievers despair of God's mercy" (4)

1- Dehkhoda, Mohammad, 1998, Persian Dictionary, Tehran Publishing, Tehran University Press.

2- Mustafavi, Hassan, Research in the words of the Holy Quran, book translation and publishing company, 1982, vol. 14, p. 223.

3- Sajjadi, Seyed Jafar, Farhang-e Maaref-e-Islami, Tehran, University of Tehran Press, 1994, 3rd, vol. 3, p. 2112.

4- Surah Hood, verse 1, translated by Ayatollah Makarem Shirazi.

An infidel to God either denies the existence of truth or denies His power or denies His bounty. Anyone who believes in God must believe that God can do whatever He wants He gives and rules whatever He wills, and no believer can despair of the Spirit of God. Let his mercy be despairing, for the despair of the spirit (mercy) of God is in fact limiting his power, In the sense of disbelief, it encompasses the extent of His mercy). 1)Hazrat Ali (AS) says: He is the highest of despair and despair (.) 2) The source of despair 
Among the cases in which man despairs and despairs pervades his existence:

1- Infidelity: If a person does not believe in God, His mercy and power in doing anything

And the cause of goodness should know its means to something else. While all the goodies in

It is the mighty hand of God Almighty. ) 3)

2 - Neglect: The united man after believing in the God of the universe if in a matter of affairs to

The mediator of negligence is to despair of the emptiness and mercy of his Lord, while being attached to

One of the attributes of infidels is characterized. 4)

3 - Ignorance and despair

4 - The temptation of the devil

5 - Not paying attention to the wisdom of life's difficulties

1- Translation of Tafsir Al-Mizan, vol. 11, p. 233

2- Surah Yusuf, verse 87, translated by Ayatollah Makarem Shirazi

3., -Great sins, Ghadir Publications, vol. 1, p. 77

4-Ibid., P.78

Types of despair) 1) From the words of the infallibles, it can be concluded that despair is an attribute for human beings that can also

To be considered as moral virtues and also as vices. So despair is of two kinds:

1- Despicable and disgusting despair:

2- Praised and well-liked despair: A (Honor of the believer: Imam Sadegh) AS (: »Hope to give up what People are the source of religious dignity of the believer ") 1-1)

B (The best wealth of Imam Mohammad Baqir: »The best wealth is trust in God and greed to turn a blind eye to What people have. ) 2-1)

C (comfort of human soul: Imam Sadegh) AS (»The most comfortable comforts of man, despair of people

) 1-3 The effect of despair) 2)

1- Leaving slavery

2 - Dare to commit a sin

Treatment of despair) 3)

1- Promises of Divine Mercy 2- Thinking 3- Being open in repentance 4- Remembering the lives of the prophets and

Holy saints

The souls of the people are the ones who despair of the souls of the people of the disbelieving people (Surah Yusuf, verse 87) 
O my sons! Go to Egypt again and look for the Prophet Joseph and his brother and from

Do not despair of God's mercy, the truth is that except for the group of disbelievers, from God's mercy

Do not despair.

1- Allameh Majlisi, Mohammad Baqir; Sea of Lights, Lebanon, Al-Wafa Institute, Beirut, 51414, vol. 75, p. 241 (1-1 () Sheikh Hur

Ameli, p. 442 (,) 2-1 () Sheikh Har Ameli p. 442 (-) 3-1 () Allama Majlisi p. 4)

2- Explanation of the hadith of the soldiers, intellect and ignorance, p.138

3- Hosseini Baharan Chi, p. 217

School of Nihilism

The word nihil has an Latin origin meaning "nothing" in French dictionaries (larovsse grande (synonym of this word in Persian) (reia) and its English synonym (nothings) is therefore nihilism which in Persian's terms can be called "nihilism".

"Nihilism" is called "nihilism and apathy" is the way in which subjects are analyzed. It somehow negates human thoughts. This negation, both philosophically; That is why and how it is "recognized" as well as socially and including contracts.

It is a cumbersome imposition, which nihilism basically rejects. Nihilism The word nihilism means that "supreme values" derive their value from They shake hands or why there is no answer) 2) In nihilism there is basically no value left or Because there is no reason or direction because there is no motivation left for a person to adhere to those values Take heart and execute them.Nihilism in the moral and epistemological realms, in fact, whenever the criteria of human judgment in the realm of There is and must be self-destruction, a person suffers from nihilism; That is, man by his own standards Loses and can not prefer one moral and epistemological option to another Give. In this case, man, in every action he takes, faces the ultimate aimlessness of mankind

He sees himself and finds all his deeds in vain and in essence and absurd. From this perspective, life is a kind of human being with pain and suffering and death and change, in any sense And a goal remains empty; That is, when a person asks himself whether to live and live whether he prefers not to or not, he can not provide any answer for it. Answer these questions

It becomes impossible because there is no good reason to choose and prefer one over the other does not have.) 3)

1- Ghafouri, Ali Notes on Nihilism p.37

2. Nietzsche, Friedrich Wilhelm, From the Will to Power $\mathrm{p}$

3 - The same, a very human being, p. 81

Desperate Philosopher (Spinoza, Nietzsche)

Spinoza's philosophy Spinoza, who was expelled from the Jews, and from the group of Christians who deny him atheism. They thought. He was scared and spent the rest of his life empty-handed. He's for a living he was engaged in cutting and installing spectacle lenses) and it is even thought that he died as a result it was an infection that arose from the glass dust in his lungs (and philosophy at timesin his spare time he wrote to the saints in his personal life more than any other great philosopher it was as if on the day of his death he was calm and fearless, and life despite the vicious attack 
The malice that befell him never got angry and he lost his sensible temper. Nadad Spinoza writes: I found from experience that all the normal things that people pursue in life. It is vain, and none of the things that frighten me are good or bad in themselves. It's not and only the mind is influenced by them, I finally decided to investigate whether. It is something that is really good and can convey goodness and thought only under its influence

And get rid of everything: Could it really be something that I discovered and achieved? To be able to enjoy lasting and lasting happiness. That's the decisión I was thinking unreasonably and cautiously about what is reliable for it What is not sure to lose. And I was also aware that if you dedicate yourself apart If I look for something other than that, I will have to forgo those benefits. on me It was clear that if true happiness happened to be in fame and fortune, I would inevitably lose it Gave while if the opposite is not happiness in fame and fortune and I pay attention to it If I spend, I will fail on the same basis.)

\section{1) Life from Nietzsche's point of view}

This is how Nietzsche portrays life, the emergence of learning and the belief that everything is It is empty, everything is the same, everything is over. Echoes came from all the hills. Everything is empty and everything is the same. Everything is over. it is true that

We have reaped, but why is our fruit ruined and black? What is the shower of the evil moon? All our work has been in vain, and our wine has been poisoned, and the evil eye has soon fallen on our crops and our hot hearts is we are all dry and if fire falls on us we will be reduced to ashes. Yes, we will burn fire too We are tired. FountainEveryone is safe.)

2) Nietzsche considers irreconcilable nihilism to be a belief in which existence is absolutely indefensible Is; When we compare it to the highest values we know, moreover, The recognition is that we have no right at all to objects of a "transcendental" or a "in essence"

Let us "believe" that "God" or morality is embodied.

1. Generalities of Philosophy, Spinoza Philosophy, p. 85

2 (-Nietzsche, said Zarathustra p. 78)

3 (-Nietzsche, the directed will p. 26)

Victor Frankel treatment. One of the methods that Dr. Victor Frankel used in his treatment was that

Introduce people to their responsibilities.)

1) Frankel believes that seeking meaning and escaping emptiness lies in the nature of human beings No one makes sense The doctor and the educator only acquaint the individual with meaning inherently "The current philosophy of mental health is based on this," says one slow semantic therapist It has been established that people should be happy and unhappy is one of the signs of incompatibility with the environment

Maybe this way of thinking is the reason why the inevitable burden is getting heavier day by day Be. People are sad, why are they sad? In another article, he hopes that this Change the current misconception in America to treat incurable patients rather than their own painLet them be proud of themselves and their suffering be proud of themselves.)

2) Frankel refers to the disease of absurdity as the disease of the present principle Disease and distress of human societies. He lost this weakness from the weakness in faith Desire counts human meaning.) 
1- Man in search of meaning, p. 831

2-Ibid., P. 831

3-Ibid., P.87

Brotherhood (thoughts, poems)

Brotherhood and his poetic tendencies

Brotherhood Because in the most critical period of political movements, to man and destiny and freedom Our traditional society, which is full of contradictions, turns like our own society Exposed to many fluctuations in the poem of hope, with various signs of its culture Let's face it. To understand the mentality of the Brotherhood, especially its tendency towards man, it must be in different periods

Examined and recognized its components, periodized his thinking tendencies, concepts and He categorized his mental components so that in general he could understand how the continuous formation of tendencies

His works were found in the heart of socio-political events, which can be divided into two periods:

1- Trend of the pre-failure period

2 - The trend of the post-failure period

In the case of the first tendency concerning human destiny, it can be interpreted as a social sense of justice

It is romantic. The period of struggle, the beginning period for the poem of hope, man and struggle for Justice, however, does not yet have the independence and diversity of a special subject such as the next period, diagram Passionate feeling is the clearest sign of his perception of social feeling in relation to revolutionary Romanism And following the thought of Shandro Petofi, the national hero and virtual romantic in the poem "Dogs and Wolves"

Appears.

Not from my soul, not from my bell, my colorless colorless. Come open the door, open it, I miss you The privacy, the host, the guest of the year and the moon behind the door tremblestNot hail, not death, someone knows my secret so turn to me (m, hope, winter) in the poems of the Third Brotherhood, one can see individual and social despair and even defeat in the face of nature observed for example;

We sat down and kept the moonlight on at night And the night was Shatt Alili "Brotherhood, from this Avesta" (p. 13)

"Dandelion ! Han, what's up where and from who did you get news, Good news, but, but Round the roof and you become fruitless in me. There is no news waiting for me, no pilgrimage, no matter what come on, where did you go?

Really, is there any news yet? Hot ash residue somewhere? I do not close the flame of greed in the stove, is it still evil? "Akhavan, p. 148, end of Shahnameh Breaking the string of fruitless hope is better than attaching in vain, I also agree that he was connected to the absolute impasse, Unless, perhaps, once again, diligence and diligence, perseverance open the way from another path "(Akhavan, p. 121, says life)

The Brotherhood's frustration is the result of a black and dark frustration that is also rooted in thought. It has the Brotherhood, and this indicates frustration and submission to the judiciary, which is straightforward And that's how it turned out.aAl Pat Pet Ranjour Candle near Death 
Bored and with the dawn approaching and the warm hand of death And then he goes out, to another drowning in the hope that it was renewed from the fresh air

But there is a hadith of disgrace and opium, from the gift of a dervish who reads: The world is old and baseless, shouting from this Farhad Kash ..... «) Third Brotherhood, M. Omid, Winter (

The Brotherhood, with its winter collection, clearly conveys its frustration to the listeners. To Assyrian saying: In this book, the Brotherhood has a painful moan. The content of the winter poetry collection is a reflection of his hatred of breaches of contract and two The colors of the helpers feel cheated and have no blame or march anymore

The green forest, not the red grove, his particular style actually begins in the second half of the series Be. I'm a guest every Saturday, Lolly I, too, am a stumbling block Sanam, Insult of Creation Post, Awkward Song, Not from my soul, not from my bell, the same colorless color (M, winter hope). The extreme despair and heavy sorrow of homelessness here is recounted in the language of the Brotherhood, his whispers with A short and melodic sentence that expresses sadness from the seemingly true deceptions and tricks, And the expression of colorlessness is expressed as the mother of a dead child who tracks her grief under her lips

He whispers and calms himself by moving. The Brotherhood finally complains about its creation and questions the universe. I am an awkward creation. Not hail, not death You hear a voice talking cold and teeth. I came tonight to lend I will put the account next to the cup (M, Omidzamestan). Brotherhood in thisJa states that not even death occurs, the echo of his voice rises.

He expresses the sentence more firmly and longer without anyone telling him anything or forbidding him. Be at work. According to the above and the hints about despair and its consequences, the result can be

He found that his despair and hopelessness caused a change in man's view of himself, those around him and society Is. It is possible that he sees society from another angle due to his short-sightedness, perhaps this short-sightedness

It dominates all life and because it changes its beliefs from another perspective See and if these situations and behaviors that are contrary to the principle of Islam and hadiths and the Holy Quran

Is, to be immersed in body and soul. And it is inevitable that man will retreat to absurdism And deprive him of the qualities that a worthy semantic man deserves, and at some point Walk in vain and emptiness and meaninglessness. Quran and Hadith treatment strategy

One of the ways to escape from despair and hopelessness is to realize God's mercy and hope in God's grace, is. In four cases, God has been asked for mercy, three of which are from the prophets and the other

It is from the pure servants of God. Baqarah / 286. Mystics / 151 and 155. / Believers / 111 The word alRahman 157 times throughout the Qur'an, and the words al-Rahim and Rahim and Rahima a total of 166 times Has been repeated and in verse 128 of Surah Tawbah, the word Rahim is used in the description of the Holy Prophet (PBUH).

A few divine messages that indicate the mercy of God. In the verse "And the Lord of Forgiveness and Mercy", your Lord is the Most Merciful, the Most Compassionate.

"And mercy and the breadth of the whole thing" and divine mercy is vast and includes everything «God has made mercy obligatory upon Himself is. Rewards / 12 and 52 From Imam Mohammad Baqir (AS) (On the grace and mercy of God)

Khifa and Noor Raja, if the weights are not Yazid, and for this, and if the weights are not, Yazid is for this; No believing servant. It is not except that in his mind there are two shining lights (fear) of the 
previous deeds and the end. The latter and (light of hope) by the grace and mercy of God that if each is compared with the other no

One will not find the means; vol. 2, p. 488.Verse 87 of Surah Yusuf, which indicates the vast mercy of God and its interpretation according to Light interpretations, sample;

"And seek refuge in the souls of the people, for they despair of the souls of the people of the disbelieving people."O my sons! Go to Egypt again and seek mercy from Joseph and his brother

Do not despair of God, the truth is that except for the group of disbelievers, they do not despair of God's mercy To be (Joseph / 87

Conclusion

As it is obvious, various works of the Third Brotherhood (M. Omid) were presented in the face of which We can point to two approaches: the first approach is the poetic poetic appearances that catch the eye of every viewer It focuses on itself and empathy and language is established between the poet and the reader. The second approach : The poetic depth of the Third Brotherhood carried other meanings.

And it fits into the personal situation and the exhausting life and other intellectual factors of the poet Took.

The result is that, considering the works of the Third Brotherhood and the biography quoted in his poems. The Brotherhood cannot be considered nihilistic and nihilistic, but according to the time period. The poet's empty and desperate thoughts in the poet's poems can not be considered unexpected. Here, we have tried to use verses and hadiths and from a purely critical point of view, the poems of this Evaluate the great poet with evidence of Western culture and the basis of this thinking.

References

1- The Holy Quran, Surah Yusuf, translated by Makarem Shirazi

2- The Third Brotherhood, Mehdi (M. Omid (1992)) The End of Shahnameh, Tehran, Morvarid Publications, Tenth Edition
$3($, -1371,) Organon, Tehran, Morvarid Publications, ninth edition
4 ((, ------------------ 1361) of this Avesta, Tehran, Morvarid Publications;
5 ,„, --------------- -1348, The Best Hope, Rosen Publications, First Edition.
6 ((, ------------------- 1368,) In the small life of autumn in prison, Tehran, Publications

\section{Bozorgmehr}

7 (, ------------------ 1371,) Winter, Tehran, Morvarid Publications, 13th edition

8 (, ------------------ -1357,) says life but must live, Tehran, Publications

1 -Papkin Richard Henry, Avrum Stroll, 1123, Generalities of Philosophy, translation;

, 581, Tehran, Hekmat, first edition) new edition (2002, No. $1431 \mathrm{AH}$

11- Hosseini Baharan Chi, Seyed Mohammad; Muharrams of Islam, Atrat perfume, 2006, first, p.217

11- Khomeini, The Spirit of the People, Explanation of the Hadith of the Soldiers of Wisdom and Ignorance, Tehran, Institute for Organizing and Publishing the Works of Imam 
CRITIQUE OF THE CATEGORY OF DESPAIR IN THE POEMS OF THE THIRD BROTHERHOOD WITH THE APPROACH OF THE QURAN AND THE HADITHS OF THE IMAMS (PEACE BE UPON THEM)

Khomeini (RA), 2003, the seventh

12-Dastgheib, Abdolhossein, .Ginhahan Kabireh, Ghadir Publications, 1996, Vol.

13 - Dehkhoda, Mohammad, 1998, Persian Dictionary, Tehran Publishing, University Press

Tehran.

14 - Sajjadi, Seyed Jafar; Farhang-e Maaref-e-Islami, Tehran, Publications.

15- Sheikh Har Ameli, Mohammad Ibn Hassan, Shiite tools, Qom, Al-Bayt Institute for the Revival of Heritage,

$1 c, 1411$

16-Tabatabai, Mohammad Hossein, Tafsir Al-Mizan Translation, Volume 4, Qom Publishing: Seminary Teachers Association

Theology of Qom, 1992

17- Ghafouri, Ali, Notes on Nihilism Publications of Islamic Culture Publications.

18-Majlisi, Mohammad Baqir, Bihar Al-Anwar, Lebanon, Al-Wafa Institute, Beirut, Ch 1414, vol.

11- Majlisi, Mohammad Baqir, Bihar Al-Anwar, the subject of the hadiths of the Imams, the publisher of the books of Al-Salmiya.

21 -Mokhtari, Mohammad. 1993) Man in Contemporary Poetry, Tehran, Toos Publications, First Edition

21 - Makarem Shirazi; Nasser, Tafsir Nomoneh, Tehran, Dar al-Kitab al-Salemieh, 1995, vol.

22- Mustafavi, Hassan, Research on the words of the Holy Quran, Book Translation and Publishing Company, 1982

C 14, p 223

23-Nietzsche, Friedrich Wilhelm, The Will to Power, translated by Majid Sharif, Jami Publications,

Print 1377

24-Ibid., 1314, ) Very human, translated by Saeed Firoozabadi, Publisher: Jami, Subject

Philosophy and logic, turn 6

25 - The same, said Zarathustra, translated by Dariush Ashouri, Nili Publications, 1352

26 - The same, the will to power, Mohammad Sharif, Hami Publications, 1998 